\title{
Unresectable Lung Non-Small Cell
}

\section{Carcinoma}

National Cancer Institute

\section{Source}

National Cancer Institute. Unresectable Lung Non-Small Cell Carcinoma. NCI Thesaurus.

Code C155901.

Lung non-small cell carcinoma that is not amenable to surgical resection. 